\title{
Life history of Nippoleucon hinumensis (Crustacea: Cumacea: Leuconidae) in Seto Inland Sea of Japan. I. Summer diapause and molt cycle
}

\author{
T. Akiyama*, Masamichi Yamamoto \\ Ushimado Marine Laboratory, Okayama University, Ushimado, Okayama 701-4303, Japan
}

\begin{abstract}
The life history of the cumacean Nippoleucon hinumensis was investigated in the Seto Inland Sea of Japan from August 1998 to February 2002. The population produced 1 generation per year and recruitment of offspring occurred in April. The post-marsupial period consisted of 8 instars in males and 9 (plus generally 2 repeated instars) in females. Post-marsupial development up to the 4 th instar (2nd juvenile stage) was characterized by periodic molting at intervals of $10 \mathrm{~d}$, slow growth rate, and suppression of sexual dimorphism. Thereafter, the juveniles entered a long-term summer diapause from mid-May to early December, during which the ambient seawater temperature ranged from 15 to $28^{\circ} \mathrm{C}$. Ninety-nine $\%$ of the population during the diapause were at the 2nd juvenile stage, and $1 \%$ were at the 1 st juvenile stage. In December, the cumaceans resumed growth, characterized by a fortnightly molt cycle, until the females began to incubate the first brood in late February. Each molting was highly synchronized among individuals and phased with the lunar cycles. After the end of the summer diapause, sexual dimorphism became apparent, with ovigerous females becoming about 1.2 times larger than adult males. After release of manca larvae in early April, most females incubated a second brood in late April, and then rapidly disappeared due to mortality probably caused by high water temperature. Clutch size was $57.9 \pm 9.4$ for the first brood and $42.4 \pm 7.3$ for the second.
\end{abstract}

KEY WORDS: Crustacea $\cdot$ Cumacea $\cdot$ Leuconidae $\cdot$ Life history $\cdot$ Summer diapause $\cdot$ Molt cycle $\cdot$ Semilunar rhythm

Resale or republication not permitted without written consent of the publisher

\section{INTRODUCTION}

Annual fluctuations in ambient temperature comprise an important environmental factor affecting animal life. Many terrestrial animals have developed physiological mechanisms of diapause, whereby growth is arrested during the winter or summer season when ambient temperatures are too severe for survival. A number of studies on insects have documented a diapause in many species (e.g. Danilevsky 1961, Masaki 1983). Although crustaceans are comparable with insects in abundance and morphological diversity (Brusca \& Brusca 2002), their diapause has not so extensively been studied as in insects. Crustacean dormancy has mainly been studied in freshwater groups such as ostracods, copepods and cladocerans (Alek- seev \& Freyer 1996, Brendonck et al. 1998). Although the diapause has been studied in some marine copepods, dormancy seems less common in marine than in freshwater crustaceans, probably because of the environmental stability of the sea.

Peracarid crustaceans, which include amphipods, isopods, mysids, tanaids and cumaceans, comprise a large part of epibenthic macrofauna from shallow waters to the deep sea. Most of the 1200 cumaceans reported are marine species. Life history studies of cumaceans have revealed that their life span usually ranges from a few months to a few years (Forsman 1938, Krüger 1940, Corey 1969, 1976, 1983, Gnewuch \& Croker 1973, Valentin \& Anger 1977, Granger et al. 1979, Bishop 1982, Duncan 1984, Jarre 1989, Roccatagliata 1991, Bishop \& Shalla 1994, Cartes \& Sorbe 
1996, Corbera et al. 2000, Yoda \& Aoki 2002). In general, the cumacean life span seems to be related to ambient temperature, with lower temperatures resulting in a longer life span (Duncan 1984). However, most studies of cumaceans have concentrated on species living in the temperate Atlantic (Roccatagliata 1991); comparative studies in other climatic regions or depths are necessary in order to elucidate the specific adaptation of cumaceans to environmental temperatures.

The cumacean family Leuconidae generally lives in cold waters, such as in the deep sea or on the continental shelves of cold latitudes (Jones 1969, Bacescu 1988). The life history of leuconid cumaceans has been studied in 2 deep-sea species, Leucon jonesi (Bishop 1982) and Leucon profondus (Bishop \& Shalla 1994), and a shallow water species, L. nasica, in the Gulf of Saint Lawrence (Granger et al. 1979). The life span of these cold-water species comprises a few years. The geographic distribution of the Leuconidae in Japanese waters is characterized by a southern extension of the habitat to warmer regions such as shallow bays and brackish lakes in Honshu (Gamô 1967). High water temperatures during the summer season in these habitats are presumably hazardous for the leuconid cumaceans (which originated from cold waters), and therefore these must possess various adaptations to cope with high water temperatures. We found that in the central region of the Seto Inland Sea of Japan, a great majority of Nippoleucon hinumensis undergo a long-term summer diapause in the juvenile stage, with a very small number of individuals showing a nondiapausing mode in their life history. The present paper deals with the great majority of the $N$. hinumensis population which shows a summer diapause unique among crustaceans. In a succeeding paper (Akiyama \& Yamamoto 2004, this volume), we describe the small population of the $N$. hinumensis population with a non-diapausing mode.

The present study also addresses inter-individual synchronization of reproduction, and embryonic and post-embryonic development in Nippoleucon hinumensis. Some previous field studies have focused on the timing of developmental events in crustaceans (Klapow 1972, DeCaursey 1983, Sastry 1983). Through intensive field sampling over $3.5 \mathrm{yr}$, we reveal a distinct inter-individual synchrony of the molt cycle phased with the semilunar cycle.

\section{MATERIALS AND METHODS}

Study site. Nippoleucon hinumensis (Gamô, 1967) was collected in the central region of the Seto Inland Sea of Japan in the NW Pacific. The sampling site (off Ushimado, Okayama Prefecture; $34^{\circ} 36^{\prime} \mathrm{N}, 134^{\circ} 09^{\prime} \mathrm{E}$ ) is estuarine, near the mouth of a bay into which flow 4 rivers. The water temperature at the study site fluctuated seasonally from $8^{\circ} \mathrm{C}$ (February) to $28^{\circ} \mathrm{C}$ (August and September).

Collection. The sampling station was at a single site at a depth of $6 \mathrm{~m}$ throughout the investigation. Preliminary investigation had confirmed that Nippoleucon hinumensis lives at the surface of muddy substratum down to a depth of ca. $10 \mathrm{~m}$ throughout the year. Epibenthic sledges were used. From August 1998 through March 2000, a sledge of $46 \mathrm{~cm}$ width equipped with $500 \mu \mathrm{m}$ nylon mesh was used. After April 2000, a smaller sledge of $33 \mathrm{~cm}$ width equipped with nylon mesh of $250 \mu \mathrm{m}$ nylon mesh was used, as the larger mesh size failed to collect some specimens of 1st manca larvae. The distance of each tow was $50 \mathrm{~m}$ and towing speed was 2 to $4 \mathrm{~km} \mathrm{~h}^{-1}$. The rope length was 3 to 4 times the depth of the water. Each tow was made in the direction of the tidal current. We monitored the ship position, and the direction and speed of towing by Global Positioning System (GPS) on board the towing vessel. The muddy sediment collected by the epibenthic sledge was sieved, using a plastic basket equipped with the same nylon mesh as used in the collection sledge. From November to May, we gathered samples 2 or 3 times a week, and in the other seasons, 2 or 4 times a month; 2 or 3 sediment samples were collected on each sampling day. For quantitative estimation of population density, sediment samples were obtained using a small grab of $15 \times 15 \mathrm{~cm}$ bite from April 2001 to March 2002. On board, each grab sample was passed through a $250 \mu \mathrm{m}$ sieve; 3 grab samples were taken on each sampling day. The sediment samples were transferred to the laboratory, fixed with 5 to $10 \%$ formalin in borate-buffered seawater, and animals sorted under a dissection microscope. In some cases, living specimens were sorted from sediment samples and the specimens were preserved in $5 \%$ formalin in boratebuffered seawater.

Morphology. The specimens were measured under a dissection microscope (Olympus SZH or Leica MZ125). Carapace length was used as an index of body size. The posterior end of the dorsal surface of the pseudorostrum and the carapace were marked on paper with the aid of a drawing tube and the distance between them was measured with a calibrated caliper. The pseudorostrum was excluded because of its sexual dimorphism in the adult (Bishop 1982). Gut contents were observed by transmitted light without dissection. Nippoleucon hinumensis is characterized by distinct sexual dimorphism. Sexes were determined by the external morphology of the 4th pereopod, whose exopod in all instars is present only in the males (see Fig. 5). Intramarsupial individuals were counted and stages were determined after they were removed from the marsupium of ovigerous females. 
Developmental stage. We modified the 5 stages in the intramarsupial development proposed by Bishop (1982) to 6 stages. Stage I: spheroidal egg without distinct embryonic structure; II: embryos showing dorsal curvature with small dorsal notch; III: embryos showing dorsal curvature with distinct dorsal notch and segmentation; IV: embryos showing dorsal curvature with distinct dorsal notch and swollen buds or distinct appendages around dorsal curvature (nauplius, first postnauplius and transient stages); V: larvae after casting off embryonic membrane, showing ventral curvature with free appendages (second postnauplius stage); VI: larvae virtually corresponding to larvae at first post-marsupial instar (1st manca stage). The postmarsupial period consisted of 8 instars (1st and 2nd manca, 1st to 5th juvenile and adult) in males, and 9 instars (1st and 2nd manca, 1st to 5th juvenile, preparatory and ovigerous female); however, after the initial 9 instars, most females repeated the preparatory and ovigerous instars (see Tables 1 \& 2). The postmarsupial stages were determined on the basis of the shape of the carapace, 4th (see Fig. 5) and 5th pereopods and uropods for males, and the shape of the carapace, pereopods, uropods and oostegites plus body size for females.

\section{RESULTS}

\section{Summer diapause}

Recruitment of offspring occurred only in April and the parents disappeared from February to April; thus, Nippoleucon hinumensis in the study area produces only 1 generation per year (Fig. 1). Of note in the annual pattern was a long-term cessation of growth from May to November. The life span was divided into 3 phases: a short early growth phase from April to May; the long period without growth from May to November, and a late growth phase from December to March (Fig. 1). Carapace length of the specimens remained at ca. $0.4 \mathrm{~mm}$ from May to November. Judging from the shape of appendages, individuals stayed in the same post-marsupial stage throughout the long period without growth (see 'Post-marsupial development'). From December to May, the specimens in the early or late growth phase had food residues in their gut, except for specimens whose soft integument indicated that they had just molted. In contrast, none of the specimens that ceased growth had food residue in their guts (Fig. 2A). Thus, cessation of growth, developmental arrest, and complete fasting strongly suggested that the population entered a long-term summer diapause from June through November. Fasting began over a period of about 10 to $14 \mathrm{~d}$ in mid- or late May, when the water temperature ranged from 16 to $18^{\circ} \mathrm{C}$ (Fig. 2B-D). Re-initiation of feeding (Fig. 2E-G) occurred over a period of about 10 to $14 \mathrm{~d}$ in late November or early December, when the water temperature ranged from 15 to $17^{\circ} \mathrm{C}$. It was not clear whether these highly synchronous events were related to phase of the moon.

Shortly after entering the summer diapause, numerous spherical particles were visible in the carapace and free thoracic segments (Fig. 3A). Electron microscopic observation (M. Yamamoto \& T. Akiyama unpubl.) revealed that the particles were cytoplasmic inclusions, usually referred to as lipid droplets in electron micrographs (Porter \& Bonneville 1973). The lipid droplets occurred as early as the 1st manca instar and gradually increased in number during post-marsupial development up to the summer diapause. Just after the end of the summer diapause, lipid droplets had disappeared from the carapace and free thoracic segments (Fig. 3B).

\section{Post-marsupial development}

$$
\text { Early growth phase }
$$

In April, the offspring were released from the marsupium as 1st manca larvae (Fig. 4). These became 2nd manca larvae in late April, 1st juvenile instars in early May, and 2nd juvenile instars in mid-May. Development was so synchronous, that specimens in each sediment sample were mostly at the same instar. The larvae became larger with each molt up to the 1st juvenile instar, but 2nd juvenile instars were almost the same size as 1st juvenile instars. Nippoleucon hinumensis incubated twice in the study area. A very small number of 1 st manca larvae ( 3 to $5 \%$ of specimens in each sediment sample) appeared again in mid-May, when the great majority of the larvae released in April had entered the 2nd juvenile instar (Fig. 4; see also Fig. 9). This small group seemed to represent individuals released from the second brood, but we could not follow the post-marsupial development of the small group after the 1st manca instar. Carapace lengths did not differ between males and females. Percent linear growth over 3 molts declined progressively from $17 \%$ to about $2 \%$ both in males and females (Table 1 ). The sex ratio (males:females) of the 1st manca larvae was 0.85 in specimens collected from 30 March to 14 April $2000(\mathrm{~N}=2435)$. Fig. 5 shows the 4 th pereopod of male specimens. Although this increased in length with each molt, the exopod on the 4th pereopod (the secondary sexual character of the male) remained small during the instars before the summer diapause. Thus, sexual dimorphism was not strongly expressed in instars before the summer diapause. 

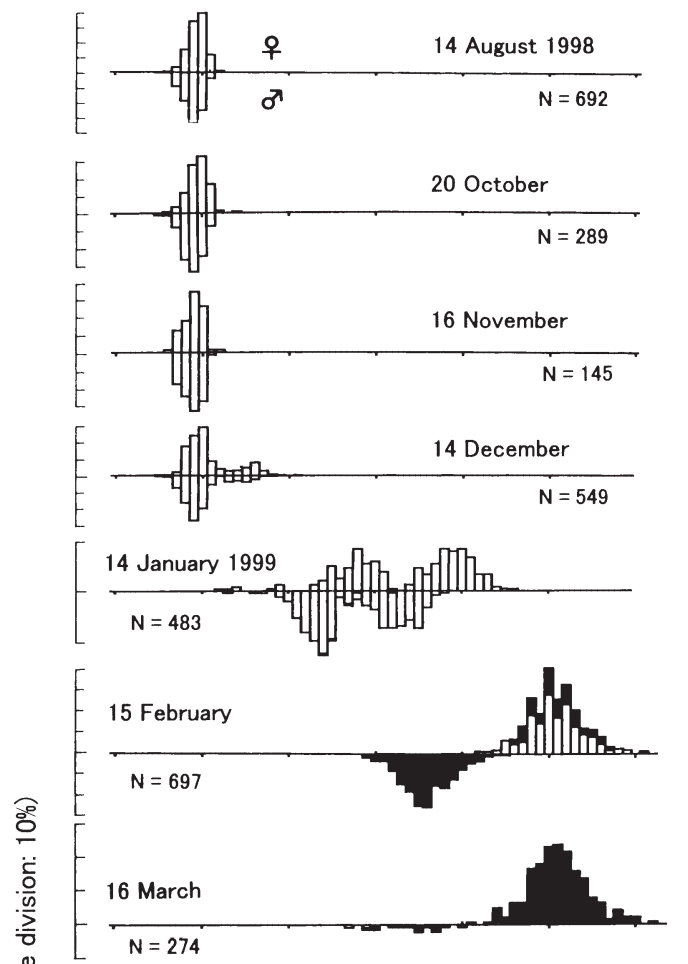

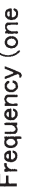
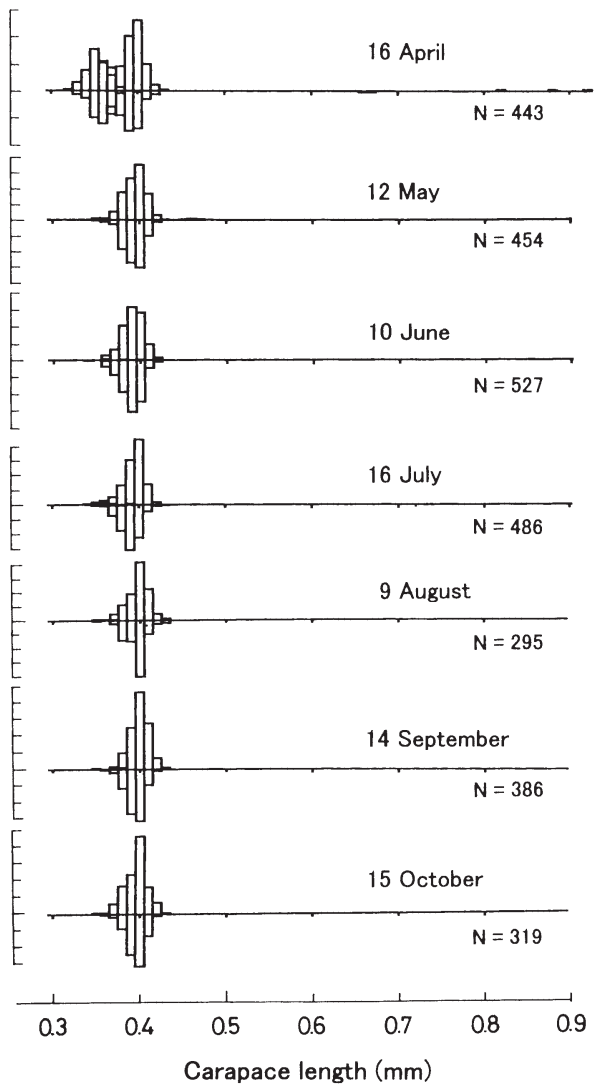
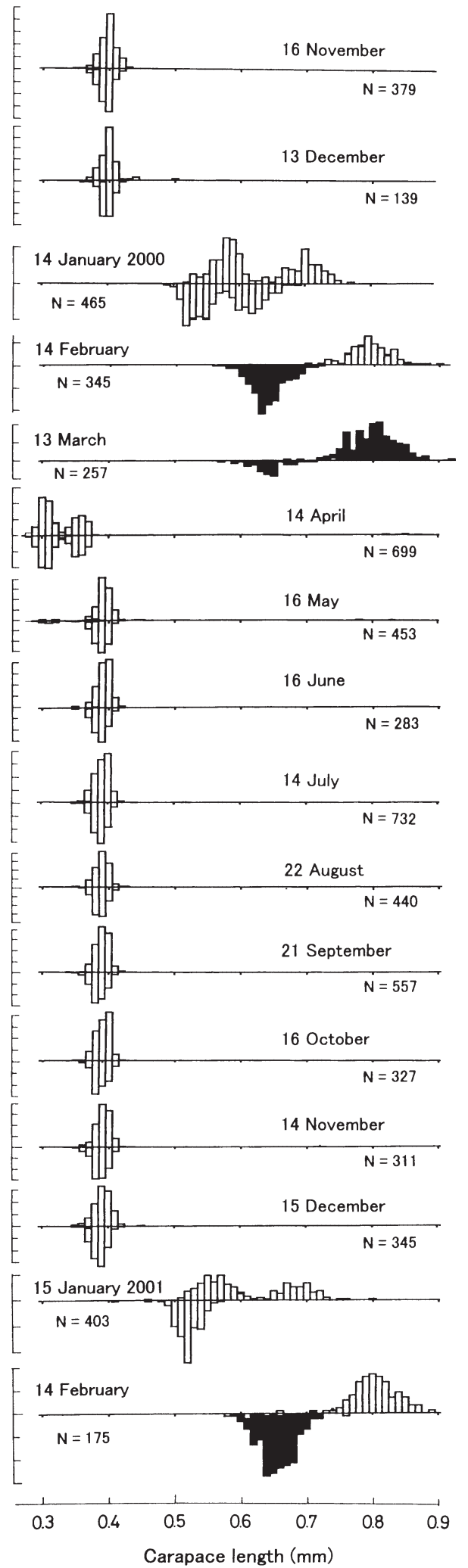

Fig. 1. Nippoleucon hinumensis. Carapace length, August 1998 to February 2001; specimens collected with epibenthic sledge. Black shading: ovigerous females or adult males; 1 division on ordinate $=10 \%$ of total number examined. N: number of specimens 


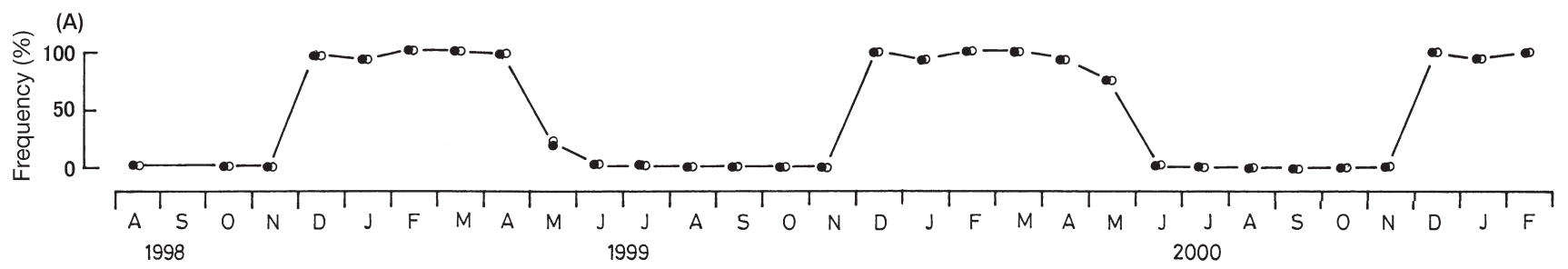

(B) $\bigcirc \bigcirc$

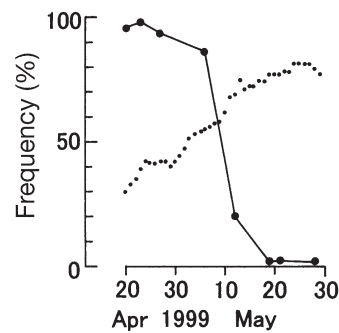

(C)

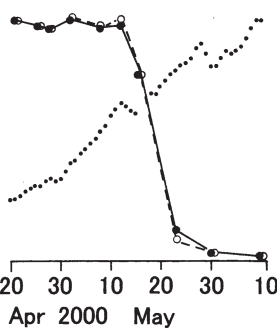

(D)

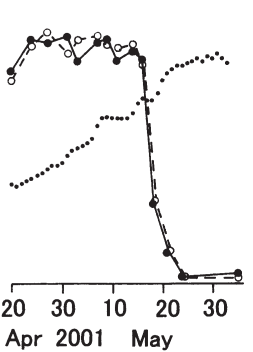

(E)

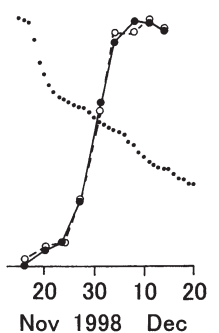

(F) $\bigcirc \bigcirc$

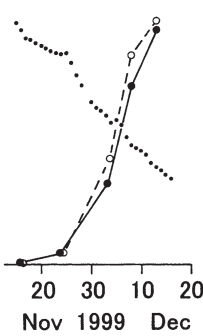

(G) $\bigcirc \bigcirc$

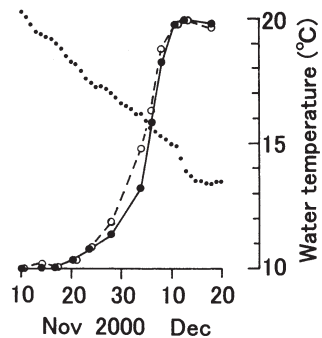

Fig. 2. Nippoleucon hinumensis. Cessation and resumption of feeding. (A) Monthly frequency (\%) of individuals with food residue in guts; samples collected around middle of each month; see Fig. 1 for collection dates and numbers of specimens examined; $(\bullet)$ males; ( $\circ$ ) females. (B-G) Temporal changes in frequency of individuals with food residue in their gut from late April to early July (B-D), and from mid-November to mid-December $(E-G)$; numbers of specimens examined per day were $174.0 \pm 85.1$ for males, $205.5 \pm$ 100.5 for females; sexes not discriminated in (B); continous line: males; dashed line: females; dotted line: daily mean seawater temperature at study site; phase of moon is shown above each graph: $(\bullet)$ new moon; ( $\mathbf{O})$ first quarter; (O) full moon; (@) last quarter

\section{Summer diapause}

Individuals derived from the first brood entered the summer diapause after they had developed to the 2nd juvenile instars. Comparison of the shape of the appendages revealed that $99.0 \%$ of the specimens in diapause (3549 of 3606 males and 4495 of 4545 females) were at the 2nd juvenile stage (4th instar) (Fig. 3A), but the remaining $1 \%$ was at the 1 st juvenile stage (3rd instar). The carapace lengths of the 1st juvenile instars in diapause were $0.359 \pm 0.013$ for males and $0.361 \pm 0.013$ for females, significantly smaller $(\mathrm{p}<$ 0.01 ) than those of the 1st juvenile instars developing before the summer diapause (Table 1). We regarded the 1st juvenile instars in diapause as individuals derived from the second brood (see 'Discussion').

Late growth phase

Individuals grew rapidly during the period December 1998 to February 1999 (Fig. 6). A stepwise increase
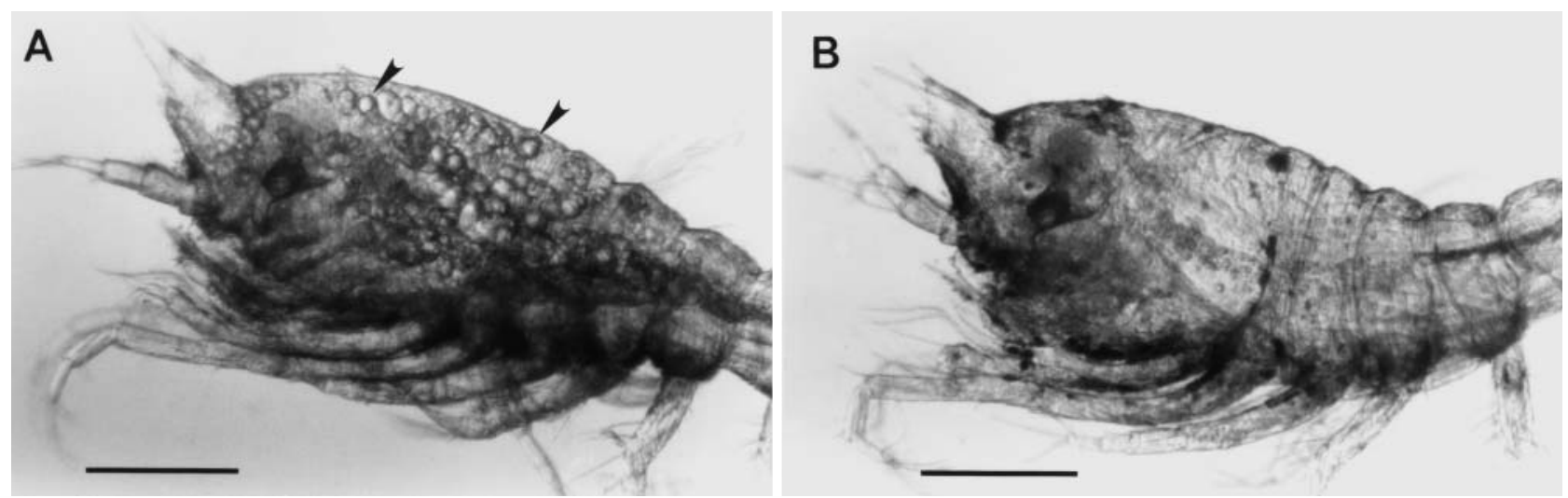

Fig. 3. Nippoleucon hinumensis. Females at 2nd juvenile instar. (A) Shortly after entering summer diapause, collected on 24 May 2001; numerous lipid droplets (arrowheads) are visible within carapace and free thoracic segments. (B) Shortly after ending summer diapause, collected on 6 December 2000; no lipid droplets visible. Scale bars $=0.2 \mathrm{~mm}$ 


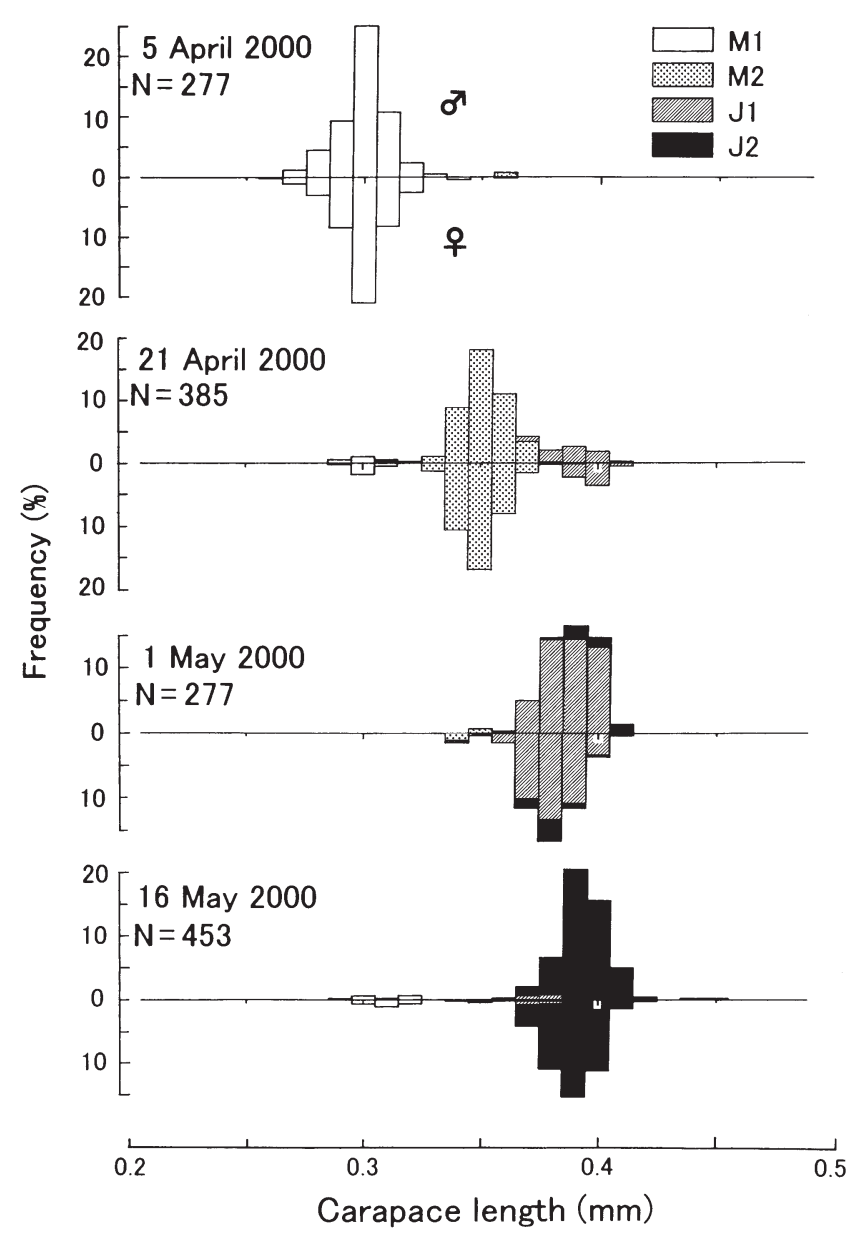

Fig. 4. Nippoleucon hinumensis. Carapace length before summer diapause. M1, M2: 1st and 2nd manca larvae, respectively; J1, J2: 1st and 2nd juvenile instars, respectively; $\mathrm{N}$ : number of specimens

in size occurred, with 4 instars in the male (3rd to 5th juveniles and adult), and 5 instars in the female (3rd to 5th juvenile instars, preparatory female and ovigerous female) after the 2nd juvenile stage. Females began to incubate the first brood in late February. After release of the manca larvae from the first brood, females incu-

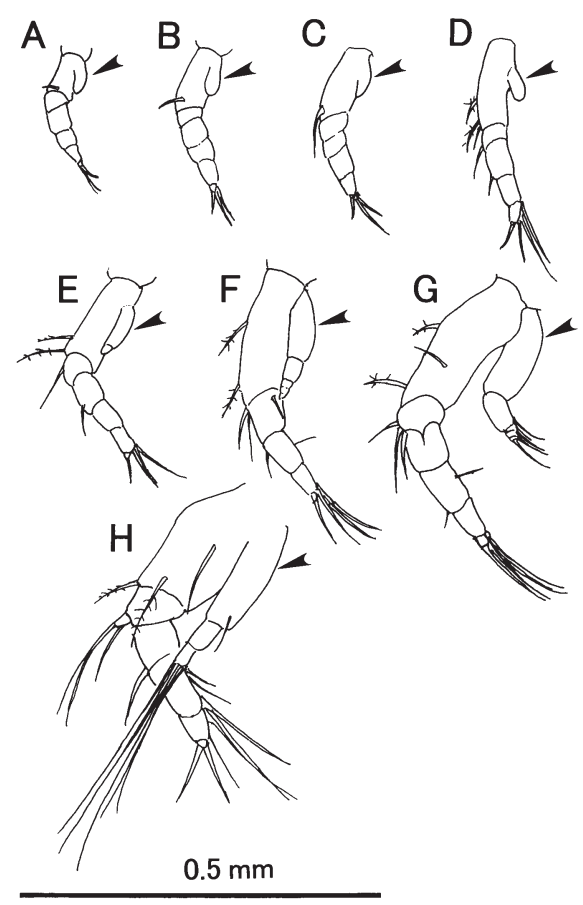

Fig. 5. Nippoleucon hinumensis. Development of 4 th pereopod in males. (A) 1st manca; (B) 2nd manca; (C) 1st juvenile instar; (D) 2nd juvenile instar; (E) 3rd juvenile instar; (F) 4th juvenile instar; (G) 5th juvenile instar; (H) adult. Arrowheads indicate exopod

bated a second brood (Fig. 7). On 30 March 1999, $58 \%$ of the females had an empty marsupium, and $30.8 \%$ of the females had entered the second preparatory stage after molting. On 7 April, $81 \%$ of the females were in the second preparatory stage, and on 27 April $97 \%$ of the females were incubating a second brood (2nd ovigerous stage). Table 2 shows the carapace length of the specimens at each developmental stage after the summer diapause. The percentage linear growth accompanying each molt from the 2nd to 5th instars ranged from 16.5 to $18.0 \%$ for males and from 15.0 to $23.4 \%$ for females. The low growth rate from the 5 th juvenile instars to adult male (5.3\%) and from preparatory female to ovigerous female $(0.5 \%)$ may have been

Table 1. Nippoleucon hinumensis. Growth before summer diapause (from 1st manca to 2nd juvenile instar). Sampling dates: 1st manca, 5 April 2000; 2nd manca, 21 April; 1st juvenile instar: 2 May; 2nd juvenile instar, 16 May. N: number of specimens

\begin{tabular}{|c|c|c|c|c|}
\hline \multirow{2}{*}{ Instar } & \multicolumn{2}{|l|}{ Males } & \multicolumn{2}{|l|}{ Females } \\
\hline & $\begin{array}{l}\text { Carapace length }(\mathrm{mm}) \\
\text { (means } \pm \mathrm{SD})\end{array}$ & $\begin{array}{c}\text { Linear growth } \\
(\%)\end{array}$ & $\begin{array}{l}\text { Carapace length }(\mathrm{mm}) \\
\quad(\text { means } \pm \mathrm{SD})\end{array}$ & $\begin{array}{c}\text { Linear growth } \\
(\%)\end{array}$ \\
\hline 1st manca & $0.298 \pm 0.011(\mathrm{~N}=190)$ & \multirow{2}{*}{17.4} & $0.299 \pm 0.011(\mathrm{~N}=229)$ & 17.4 \\
\hline 2nd manca & $0.350 \pm 0.009(\mathrm{~N}=149)$ & & $0.351 \pm 0.010(\mathrm{~N}=165)$ & $\begin{array}{r}1+.4 \\
8.6\end{array}$ \\
\hline 1st juvenile & $0.380 \pm 0.011(\mathrm{~N}=111)$ & 10.3 & $0.387 \pm 0.010(\mathrm{~N}=136)$ & 8.6 \\
\hline 2nd juvenile & $0.388 \pm 0.010(\mathrm{~N}=191)$ & 1.6 & $0.393 \pm 0.010(\mathrm{~N}=222)$ & 2.1 \\
\hline
\end{tabular}


the result of resource allocation to spermatogenesis and vitellogenesis. A rapid increase in egg volume in the ovary observed under the dissection microscope indicated that vitellogenesis began at the 5th juvenile instar. The 4 th pereopods in males after the end of the summer diapause is shown in Fig. 5D-H. Elongation of the exopods on the 4 th pereopod at each molt indicated that sexual dimorphism increased gradually after the summer diapause. The enlarged exopod with long plumose setae in the adult male (Fig. 5H) presumably improved swimming speed and manoeuverability. The sex ratio tended to increase from December to January (Fig. 8). Around 10 February 1999 and 2001, shortly before the beginning of the first incubation in the females, the sex ratio increased suddenly to around 2. Thereafter it decreased rapidly, presumably due to a sudden decrease in the number of males. From March to April, males decreased to $10-20 \%$ of females in
1999 and to $30-60 \%$ in 2001 . This suggests that most males died soon after mating. Females had all disappeared by late May following incubation of the second brood (see Fig. 13).

\section{Molt cycle}

The larvae underwent their first molt about $10 \mathrm{~d}$ after emergence (Fig. 9). Molting was synchronous among individuals within the population. Successive molts occurred at intervals of about $10 \mathrm{~d}$. The timing of each molt was identical between both sexes. It was not clear how the molt cycle up to the summer diapause was related to phase of the moon.

The molt from the 2nd to the 3rd juvenile instars occurred 2 wk or more after resumption of feeding (Fig. 10). Successive molts after the end of the summer
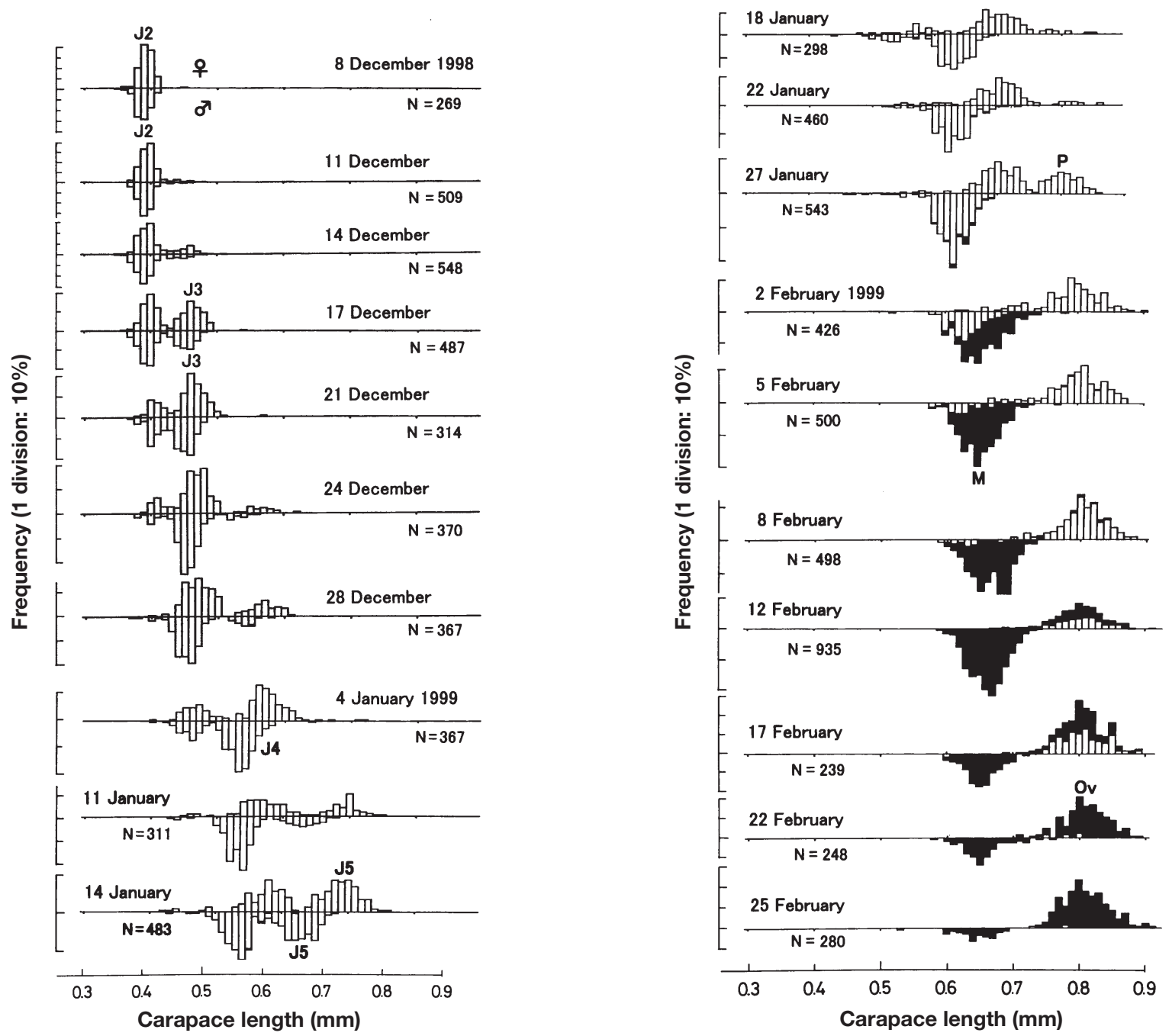

Fig. 6. Nippoleucon hinumensis. Carapace length, December 1998 to February 1999. Black shading: ovigerous females (Ov) or adult males (M). J2, J3: J4, J5: 2nd, 3rd, 4th and 5th juvenile instars, respectively; P: preparatory female; N: number of specimens 


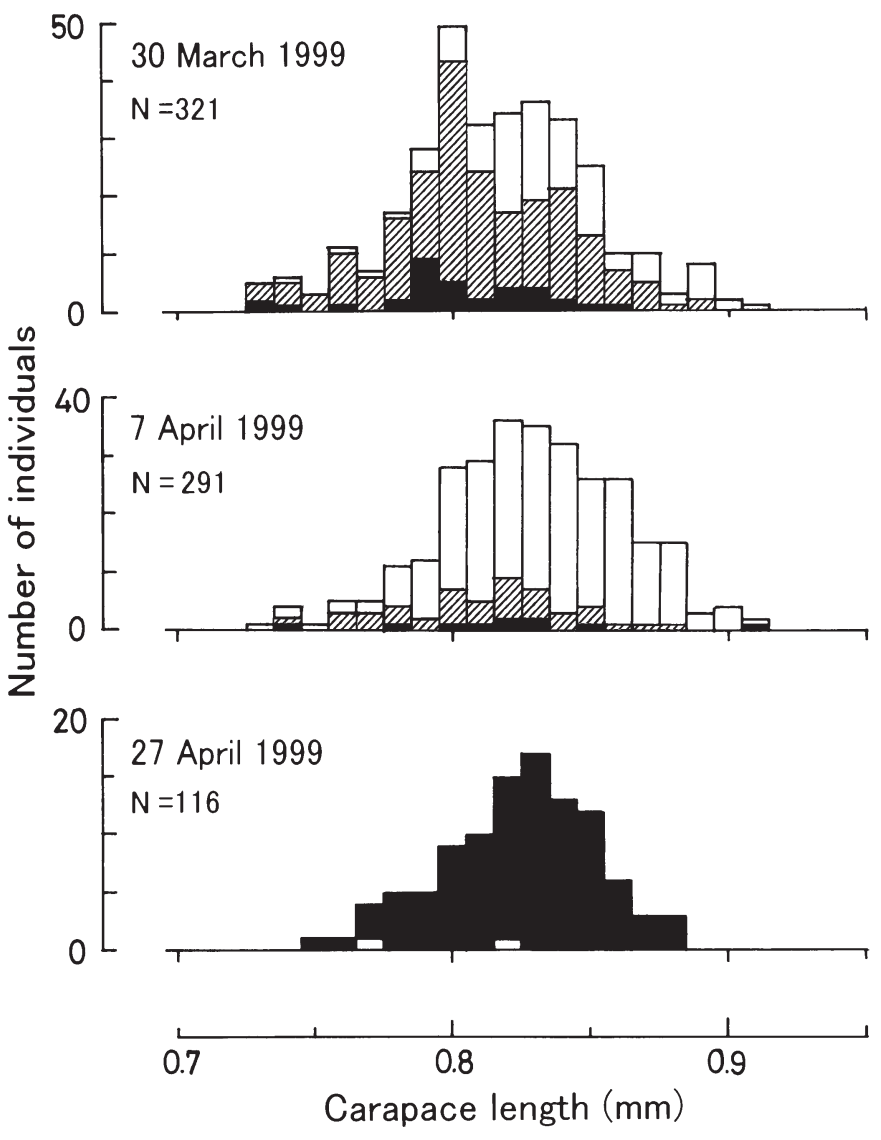

Fig. 7. Nippoleucon hinumensis. Carapace length of females from release of 1st manca larvae to incubation of second brood. Hatched bars: females with empty marsupium after release of first brood; open bars: females before second brooding (2nd preparatory stage); black bars in top graph: females with first brood (1st ovigerous stage); black bars in bottom graph: females with second brood (2nd ovigerous stage);

$\mathrm{N}$ : number of specimens diapause occurred at an interval of about $2 \mathrm{wk}$, and each molt was also synchronous among individuals within the population. The timing of each molt was the same for males and females up to the 5 th juvenile instar. The 5th juvenile instar was longer in the male (ca. 20 d) than the female (ca. 15 d). The females remained at the 1 st preparatory stage for about $20 \mathrm{~d}$, a longer period than any earlier instars. The investigation over 3.5 yr confirmed that the molt cycle after the summer diapause was related to the phase of the moon: each molt occurred shortly before new moon and shortly before the full moon (around spring tide at the study site).

\section{Fecundity}

For females during the first incubation, fecundity (no. of ind. marsupium ${ }^{-1}$ ) was $57.9 \pm 9.4$ (ranging from 30 to $77 ; \mathrm{N}=94$ ) and carapace length $0.815 \pm 0.039 \mathrm{~mm}$ (Fig. 11). The regression line between fecundity $(y)$ and carapace length $(x)$ was $y=151.6 x-65.7$. For females during the second incubation, fecundity was $42.4 \pm 7.3$ (ranging from 28 to $60, \mathrm{~N}=46$ ), about 15 less than for the first incubation, and the carapace length was $0.839 \pm 0.039 \mathrm{~mm}$. The regression line between fecundity and carapace length was $y=83.5 x-27.7$. Fecundity for the second brood was about 30\% less than for the first brood.

\section{Intramarsupial development of offspring}

A similar relationship between stages of intramarsupial individuals in the first and the second brood and

Table 2. Nippoleucon hinumensis. Growth after summer diapause (from 2nd juvenile instar to adults). Sampling dates: 2nd juvenile instar, 16 November 1998; 3rd juvenile instar, 28 December; 4th juvenile instar, 4 January, 1999; 5th juvenile instar, 22 January; adult male and Preparatory female 1, 10 February; ovigerous female 1, 25 February; preparatory female 2, 12 April; ovigerous female 2, 27 April. N: number of specimen

\begin{tabular}{|c|c|c|c|c|}
\hline \multirow{2}{*}{ Instar } & \multicolumn{2}{|c|}{ Males } & \multicolumn{2}{|l|}{ Females } \\
\hline & $\begin{array}{l}\text { Carapace length }(\mathrm{mm}) \\
\quad(\text { means } \pm \mathrm{SD})\end{array}$ & $\begin{array}{c}\text { Linear growth } \\
(\%)\end{array}$ & $\begin{array}{l}\text { Carapace length }(\mathrm{mm}) \\
\quad(\text { means } \pm \mathrm{SD})\end{array}$ & $\begin{array}{c}\text { Linear growth } \\
(\%)\end{array}$ \\
\hline 2nd juvenile & $0.387 \pm 0.011(\mathrm{~N}=76)$ & \multirow{2}{*}{16.5} & $0.388 \pm 0.010(\mathrm{~N}=69)$ & 20.9 \\
\hline 3rd juvenile & $0.451 \pm 0.018(\mathrm{~N}=143)$ & & $0.469 \pm 0.019(\mathrm{~N}=147)$ & \multirow{2}{*}{21.3} \\
\hline 4th juvenile & $0.532 \pm 0.016(\mathrm{~N}=187)$ & 18.0 & $0.569 \pm 0.024(\mathrm{~N}=143)$ & \\
\hline 5th juvenile & $0.627 \pm 0.022(\mathrm{~N}=232)$ & \multirow{2}{*}{$\begin{array}{r}17.9 \\
5.3\end{array}$} & $0.702 \pm 0.023(\mathrm{~N}=185)$ & \multirow{2}{*}{15.0} \\
\hline Adult male/ & $0.660 \pm 0.026(\mathrm{~N}=418)$ & & $0.807 \pm 0.031(\mathrm{~N}=205)$ & \\
\hline Prep. female 1 & & \multirow{4}{*}{-} & & \multirow{4}{*}{$\begin{array}{r}0.5 \\
2.8 \\
-0.6\end{array}$} \\
\hline Ovigerous female 1 & - & & $0.811 \pm 0.034(\mathrm{~N}=227)$ & \\
\hline Preparatory female 2 & - & & $0.834 \pm 31.8(\mathrm{~N}=150)$ & \\
\hline Ovigerous female 2 & - & & $0.829 \pm 31.8(\mathrm{~N}=109)$ & \\
\hline
\end{tabular}




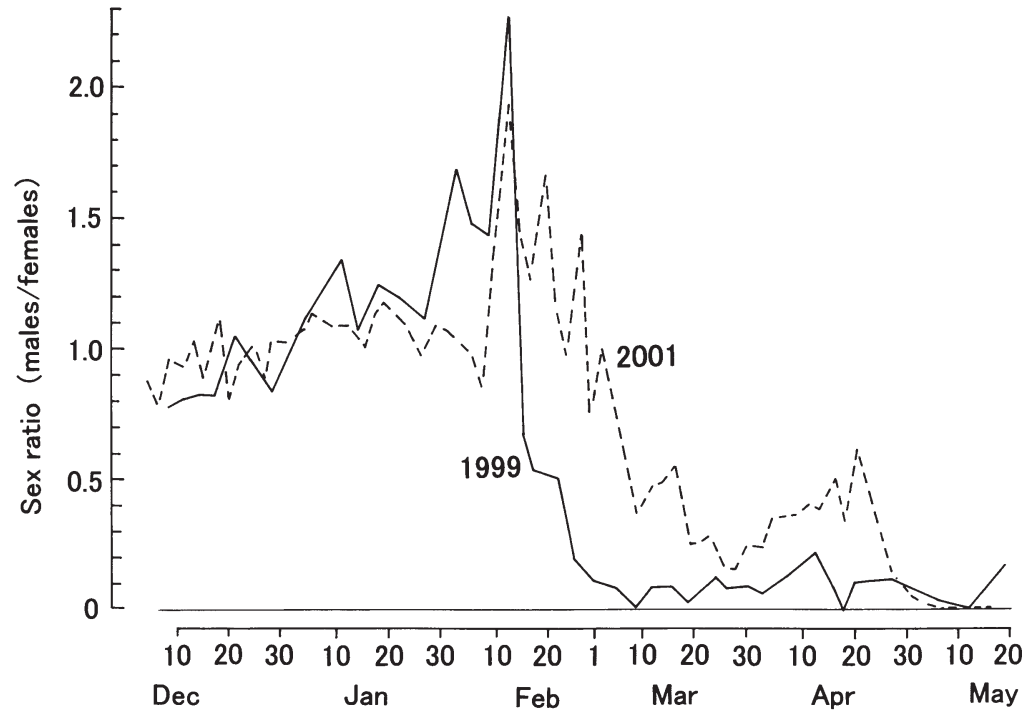

Fig. 8. Nippoleucon hinumensis. Sex ratio from December to May. Mean numbers of specimens examined each day were $406 \pm 216.6 \mathrm{SD}$

\section{Seasonal abundance}

The rapid increase in population density in early April reflected the release of manca larvae from the first brood (Fig. 13A). The mean population density in May was $93.5 \pm$ 101.4 ind. per $225 \mathrm{~cm}$ (based on 30 sediment samples). Population density decreased gradually during the summer diapause, and in late November and early December it declined to $18.8 \pm 9.1$ ind. per $225 \mathrm{~cm}$ (based on 6 sediment samples). Thus it is concluded that about $20 \%$ of the population survived the summer diapause.

After the summer diapause, the population decreased in numbers so drastically that the sediment samples collected by the grab could not provide a precise profile of seasonal fluctuations in density. Therefore we collected samples using an epibenthic sledge. This method obtained only individuals after the summer diapause, excluding coexisting offspring before the summer diapause. The trend in population density was unclear from January to March due to a large dispersion of data caused by the unstable efficiency of collection by the epibenthic sledge. From April to May, the population, mostly females with their Maximum abundance of $\mathrm{St}$ coincided with the full moon in both 1999 and 2001. The fact that the relative frequency of Stages II and III embryos reached maxima of only 20 or $30 \%$ reflected a rapid transition of these stages to Stage IV. Stage IV embryos developed to stage $\mathrm{V}$ around the new moon, about $10 \mathrm{~d}$ after the peak of Stage IV. The larvae remained at Stage V for about 7 to $10 \mathrm{~d}$. Stage VI larvae remained in the marsupium for a very short period and emerged as 1st manca larvae. Intramarsupial period for the second brood in 2001 was about $20 \mathrm{~d}$, about half the intramarsupial period for the first brood. The 1st manca larvae were released from the second brood in mid-May, 2001. The time of release of 1st manca larvae from the second brood could not be determined in 1999 because few females were collected that year but, from the transition of stages of the intramarsupial individuals, it was estimated as the first half of May.

Fig. 9. Nippoleucon hinumensis. Molt cycle up to summer diapause in (A) 2000 and (B) 2001. Dots above abscissas represent sampling days; ordinates: frequency of specimens at each instar. Occurrence of small number of 1st manca larvae (M1) from second brood is visible in May. Mean numbers of specimens examined each day were 144.1 \pm 92.1 SD for males and $157.5 \pm$ 103.0 SD for females. Continous line: males; dashed line: females; a: females with empty marsupium after releasing first brood; b: individuals with empty gut; moon phases as in Fig. 2B; other symbols as in Fig. 6
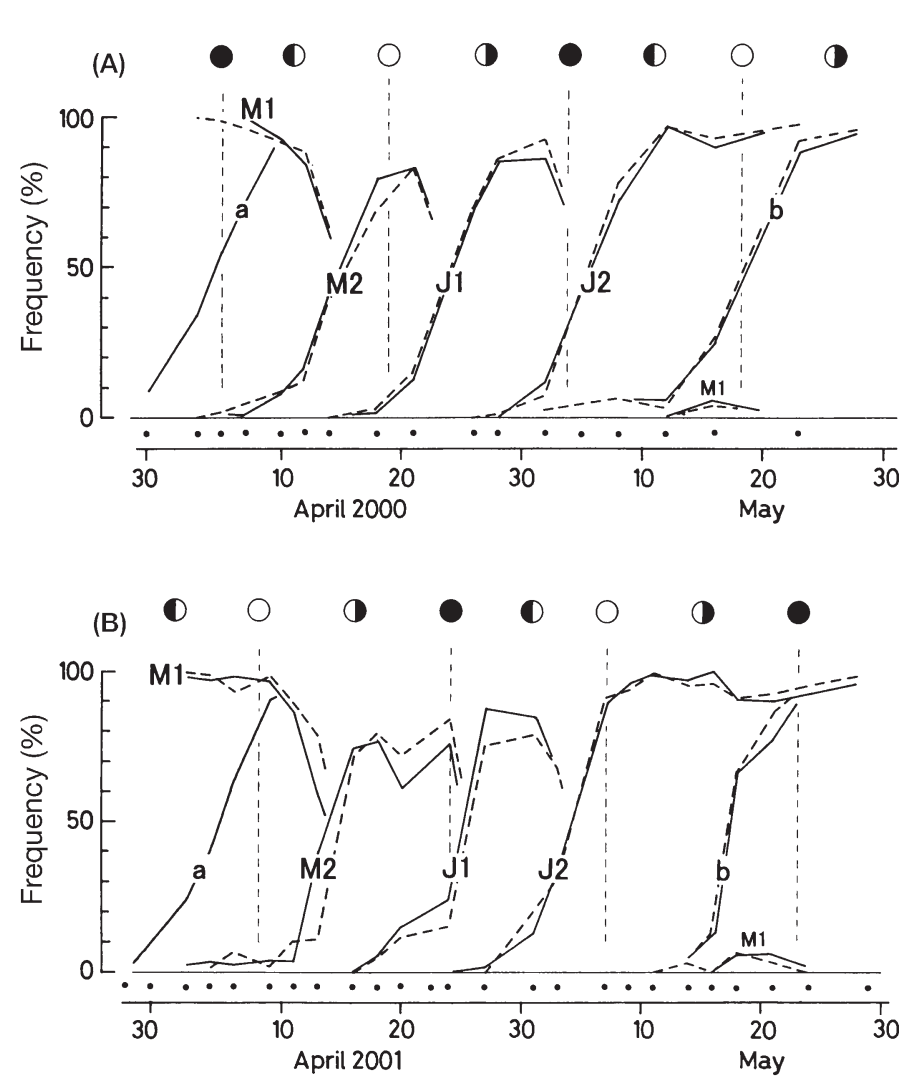
second brood, rapidly decreased in number (Fig. 13B). In late May, no adult specimens were collected.

The numbers of individuals in sediment samples collected on the same day were highly variable between sampling points: 6 sediment samples contained around 50 individuals and 1 sediment sample contained over 130 (Fig. 14). The high degree of dispersion in numbers of individuals seemed to reflect a patchy distribution in their habitat. The sediment sample with the most individuals included a higher ratio of preparatory females; the frequency of preparatory females was $25.8 \%$ for samples with $<30$ individuals, $47.6 \%$ for samples with 40 to 60 individuals, and $76.1 \%$ for the 1 sample with 138 individuals.
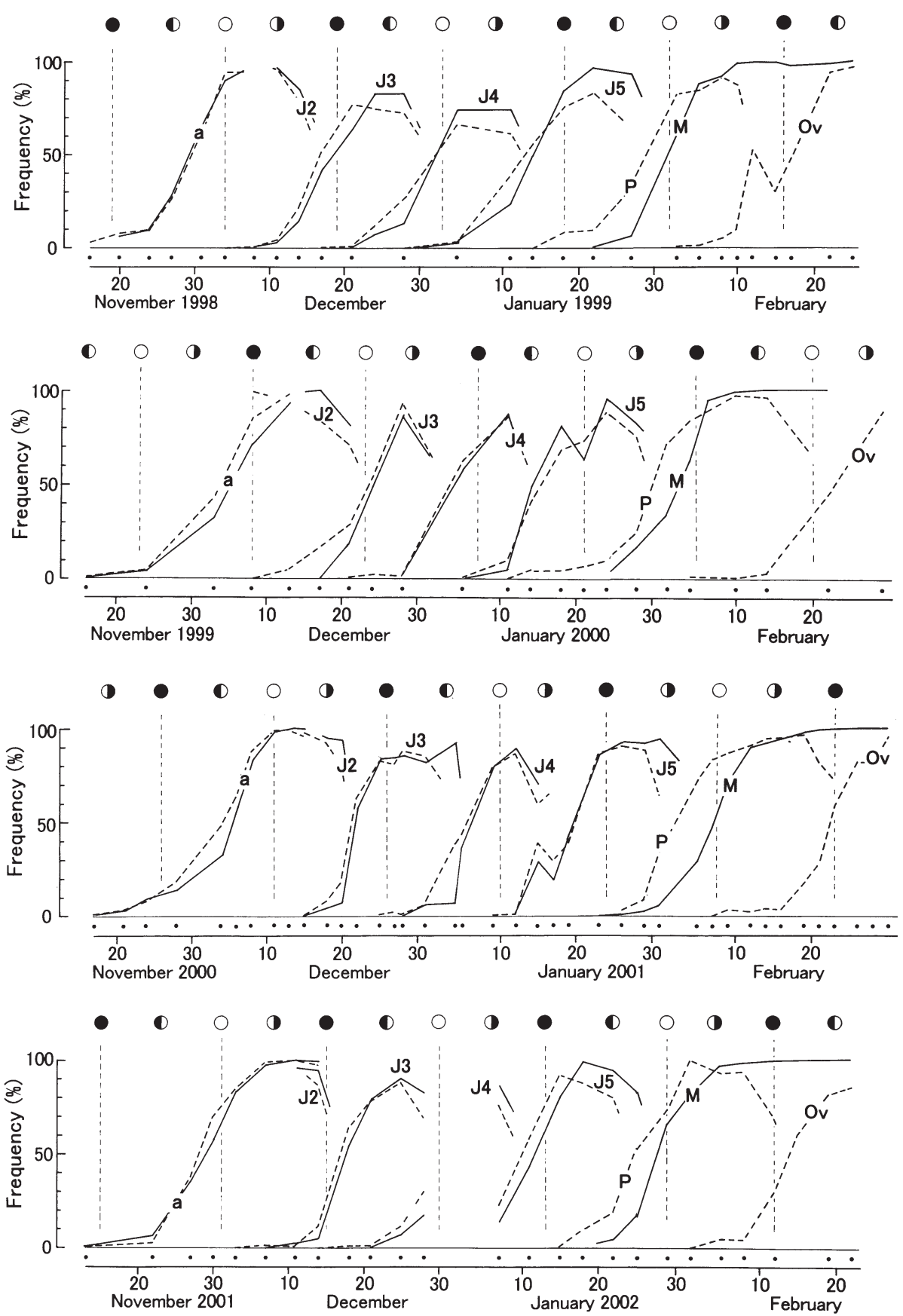

Fig. 10. Nippoleucon hinumensis. Molt cycles after end of summer diapause from 1998 to 2002. Mean numbers of specimens examined each day were 193.33 \pm 107.5 SD for males and 179.4 \pm 90.8 SD for females. Continous line: males; dashed line: females; a: individuals with food residue in gut; other symbols as in Figs. 2B \& 6 


\section{DISCUSSION}

\section{Summer diapause}

The most striking feature of the life history of Nippoleucon hinumensis is a long-term summer diapause in the juvenile instars. For about 6 mo, from summer to autumn, these individuals stopped growth, took no food, and remained at the same instar $(99 \%$ in the 2 nd juvenile instar and $1 \%$ in the 1 st juvenile). In late November, they resumed feeding and began postmarsupial development after the 4 th instar. We concluded that $N$. hinumensis undergoes a long-term summer diapause in the Seto Inland Sea of Japan.

The summer diapause in Nippoleucon hinumensis is thought to be an adaptation to survive high ambient temperatures. Of 91 known species of leuconid cumaceans, 56 live in the deep sea (Jones 1969, Bacescu 1988, 1992). A morphological characteristic of the Leuconidae is their lack of ocular photoreceptors, in both deep-sea and shallow water species (with only 1 exception), whereas in other cumacean families ocular photoreceptors are not degenerate, except for deep-sea species. This suggests that the ancestral species diverged as they entered new shallow water habitats. High water temperatures from summer to autumn in the Seto Inland Sea could be harmful to

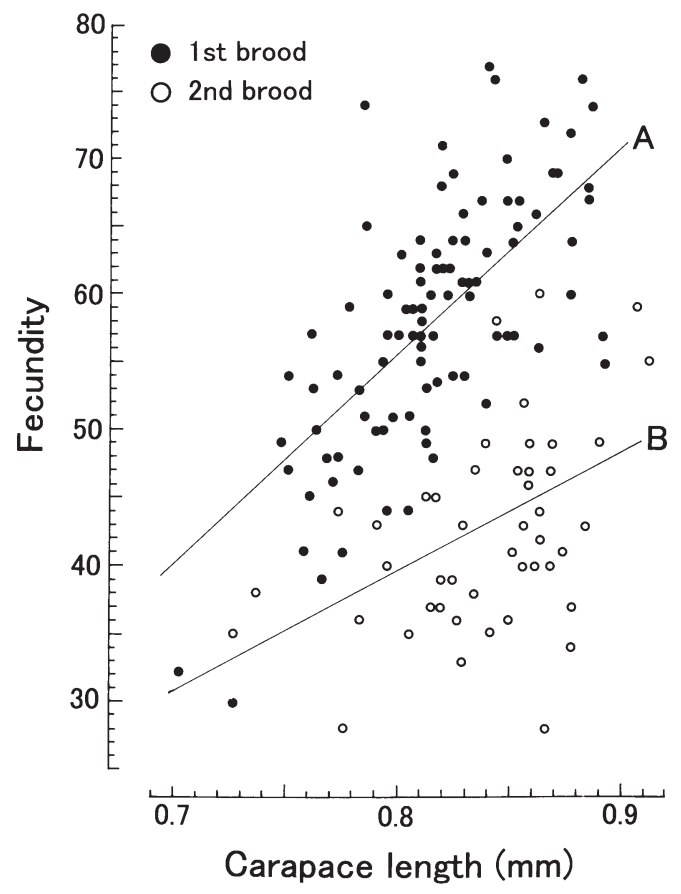

Fig. 11. Nippoleucon hinumensis. Fecundity (no. of ind. marsupium $^{-1}$ ) of first and second broods. Samples for first brood collected on 5 and 16 March 1999; samples for second brood on 16 and 20 April 1999. A, B: regression lines for first and second broods, respectively
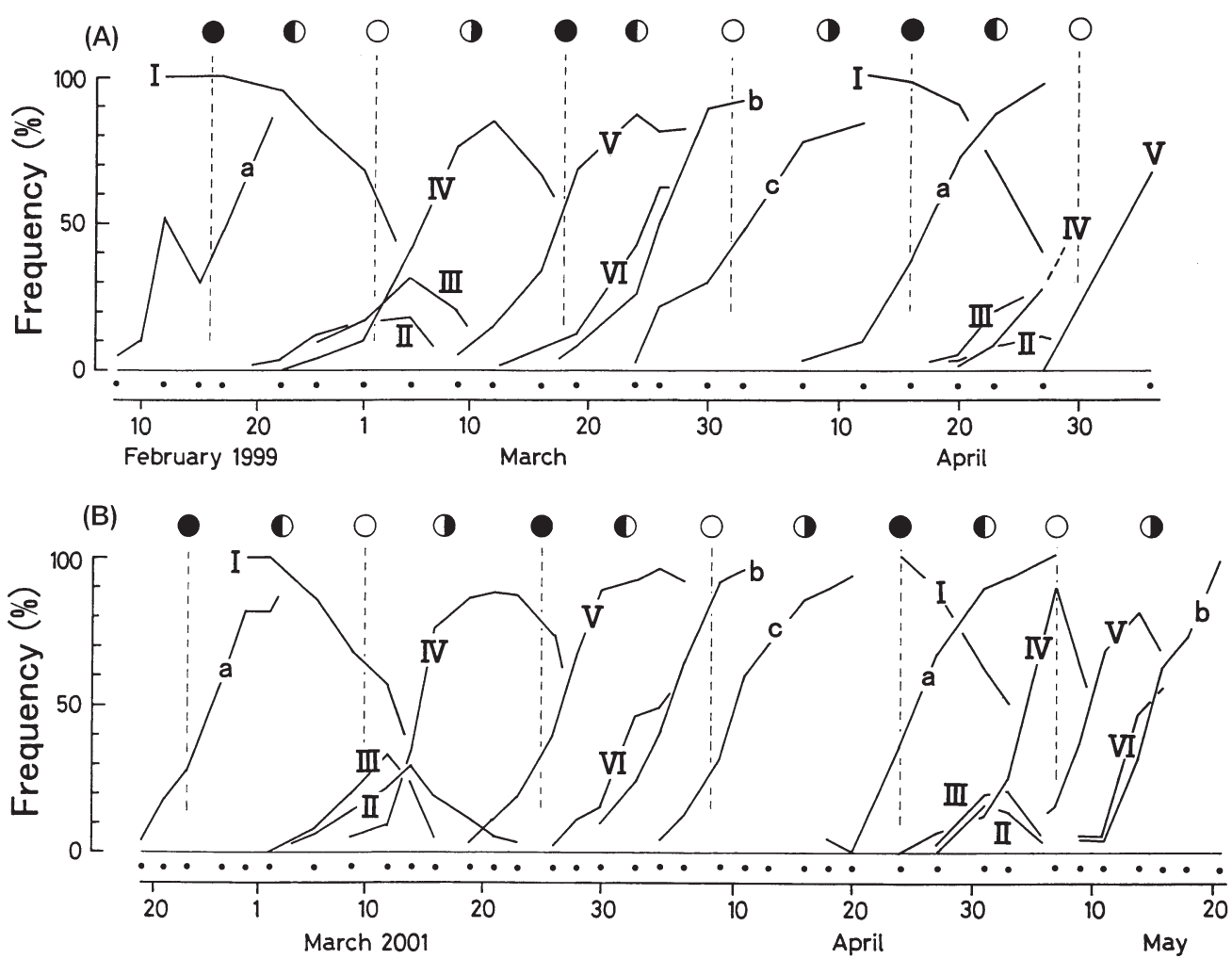

Fig. 12. Nippoleucon hinumensis. Time course of intramarsupiual development for first and second brood in (A) 1999 and (B) 2001. Each line represents frequency of the females incubating embryos at the stage indicated by Roman numerals (see 'Materials and methods'); stages on left are for first brood, those on right are for second brood. Mean numbers of specimens examined each day were 89.4 $\pm 41.4 \mathrm{SD}$ for $(\mathrm{A}), 72.6 \pm 33.7$ $\mathrm{SD}$ for (B). a: ovigerous females; b: females with empty marsupium after release of first brood; c: 2nd preparatory females; other symbols as in Fig. 2B 

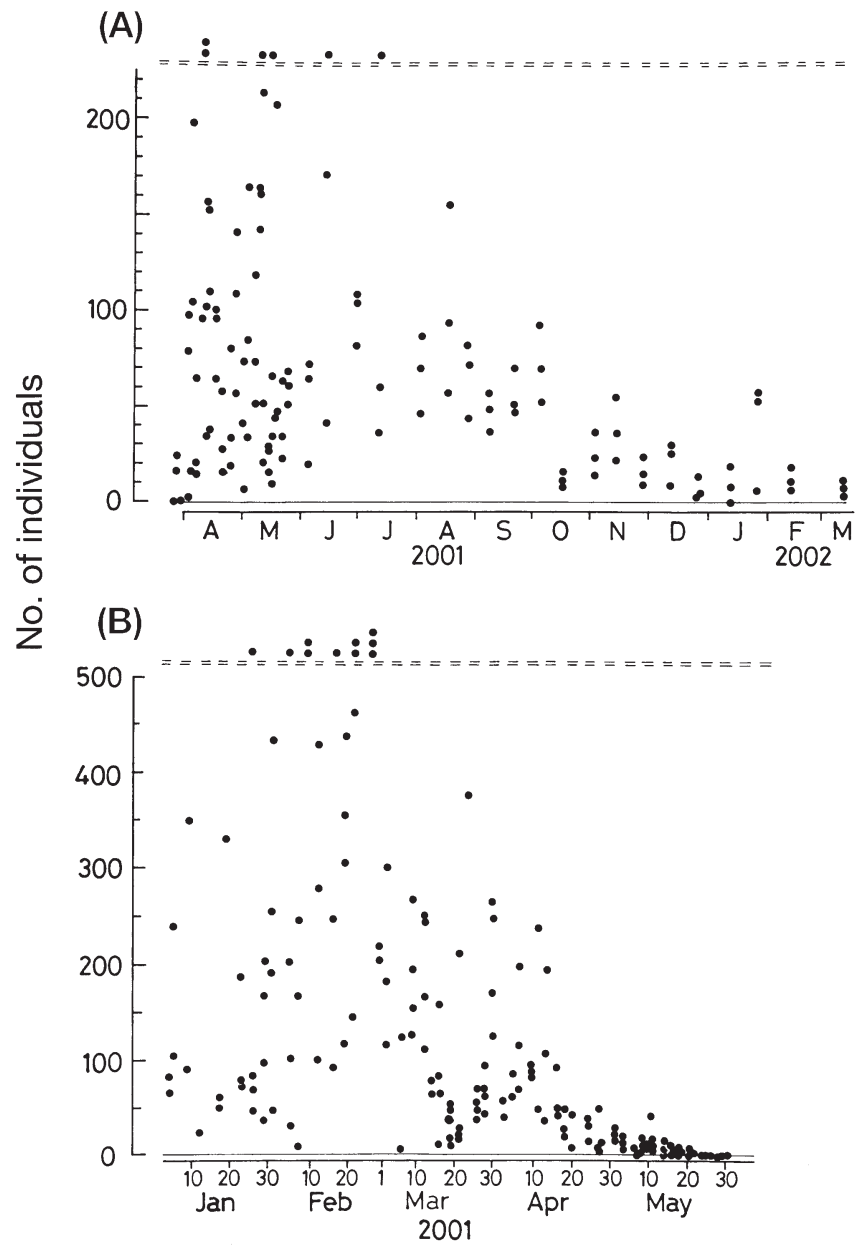

Fig. 13. Nippoleucon hinumensis. Population density. (A) Number of individuals at all post-marsupial stages included in single sediment samples collected with grab of $15 \times 15 \mathrm{~cm}$ bite. Each data point represents population per $225 \mathrm{~cm}$. (B) number of individuals after summer diapause (after 3rd juvenile instar) included in single sediment sample collected by epibenthic sledge with $21 \mathrm{~cm}$ mouth. Points above dashed lines indicate samples containing excess number of specimens

species originating from cold waters. The supply of organic particles from river outflow makes the habitat of $N$. hinumensis eutrophic, occasionally reductive, and deoxidized from summer to autumn. Entering a diapause shortly before the high-temperature season apparently ensures survival of about $20 \%$ of the $N$. hinumensis population over the summer. As a result, $N$. hinumensis is one of the dominant species in this habitat. Ecological studies of the epibenthic fauna at the study site would reveal further details of adaptive aspects of the summer diapause in $N$. hinumensis.

Long-term fasting requires stores of energy. In Nippoleucon hinumensis, many spherical bodies identified by electron microscopy as so-called lipid droplets
(Yamamoto \& Akiyama unpubl.) accumulated in the body cavity of individuals in the summer diapause. These droplets seem to be the energy source sustaining the fasting population during this time. Although the deep sea environment is oligotrophic, a seasonal increase in phytodetritus in spring provides benthic animals with sufficient food (Gage \& Tyler 1991). In such an environment, effective storage of energy resources in the form of lipid droplets would be advantageous for ancestral species of the Leuconidae. In insects, energy reserves for the summer diapause are stored as fat within the adipose tissue of the fat body (Masaki 1983). Further biochemical studies would reveal the nature of the energy stores for the summer diapause in these crustaceans.

The start of the summer diapause in May and at the end in November were highly synchronized among individuals within the population of Nippoleucon hinumensis. Presumably, such synchrony depends partly on internal physiological processes entrained by physical environmental time cues. In insects, underlying mechanisms governing the timing of diapause have been well-documented (Saunders 1982). Seasonal changes in photoperiod (day length) and ambient temperature are often utilized as effective cues to determine the timing of the diapause (Brendonck et al. 1996, Stross 1996). In the present study area, water temperature increased in May and decreased in November by $3.7 \pm 0.6$ and $5.4 \pm 0.7^{\circ} \mathrm{C}$, respectively. Fluctuation in day length in both May and November around the sampling site is ca. 45 min. Thus the photoperiod and the ambient temperature could be effective cues to determine the time of the beginning and cessation of the summer diapause in N. hinumensis.

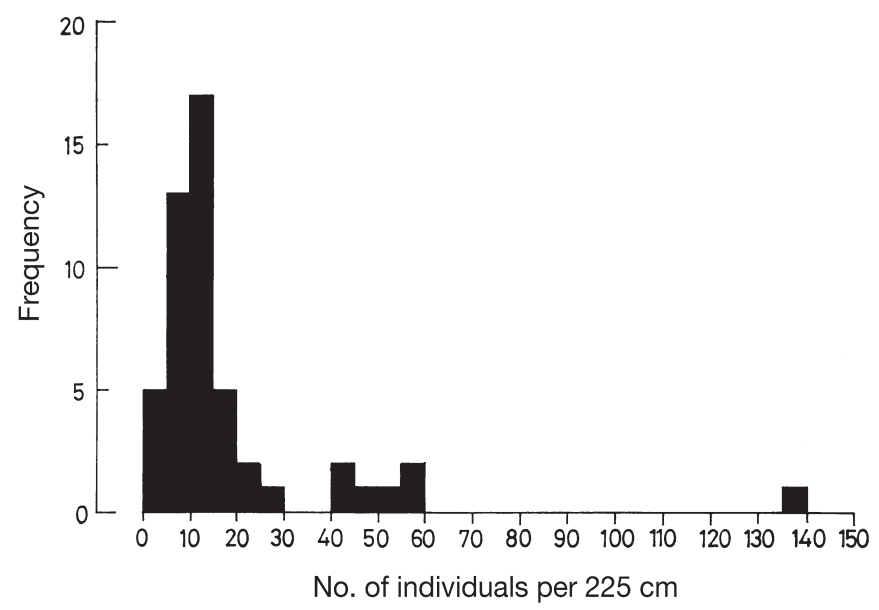

Fig. 14. Nippoleucon hinumensis. Number of specimens contained in 50 sediment samples collected with grab of $15 \times 15 \mathrm{~cm}$ bite on 17 February 1999 


\section{Molt cycle}

The molt cycle of Nippoleucon hinumensis was also highly synchronized among individuals within the population at the study site. In particular, the molt cycle after the end of the summer diapause exhibited a distinct semilunar rhythm. The ecological aspects and physiological mechanisms of the semilunar rhythms in marine organisms have been well documented in previous studies (Neumann 1981, Palmer 1995). As for the Crustacea, a distinct semilunar rhythm of the molt cycle has been reported in the isopod Excirolana chiltoni (Klapow 1972). However, the adaptive significance of a synchronous molt cycle has not been well documented. Previous studies have focused on the adaptive significance of semilunar rhythms in the reproductive behavior for effective mating in the Crustacea (Sastry 1983). The rapid death of males shortly after the appearance of ovigerous females in $N$. hinumensis suggests the presence of synchronization in mating behavior. Semilunar rhythms in the molt cycle presumably play some role in this synchrony. The intervals of the cyclic molts up to the summer diapause were evidently shorter than those after the summer diapause. Since the 3 molts up to the summer diapause were highly synchronous, we presume that some internal or environmental mechanisms controll the molt cycle. It is not certain how the molt cycle before the summer diapause is related to the phase of the moon. Since the water temperature ranged from 10 to 15 during the periods of cyclic molts both before and after the summer diapause, an effect of temperature on metabolic rate would not seem to be responsible for the difference in molting intervals between the periods before and after the summer diapause. Experimental analyses in the laboratory will be required to elucidate the mechanism of synchronization of molting in $N$. hinumensis.

\section{Growth}

The percentage increase in carapace length up to the summer diapause became smaller with each successive molt. An increase of only ca. $2 \%$ at the 3 rd molt is unusual in crustacean juveniles. This low growth rate is presumably related to the storage of lipid droplets as an energy reserve to survive during the summer diapause. After the end of the summer diapause, females grew more rapidly than males. In Leucon nasica (Granger et al. 1979) and L. jonesi (Bishop 1982), in contrast to Nippoleucon hinumensis, adult males are larger than females and the growth rate is higher in the male than in the female. Sex-related differences in growth are presumably related to specific adaptations.

\section{Reproduction}

Cumaceans occasionally incubate 2 broods (Duncan 1984), as observed in the deep-sea leuconid cumacean Leucon jonesi (Bishop 1982). It is generally difficult to estimate the frequency of females that incubate a second brood from specimens collected in the field. Corey (1976), using Diastylis sculpta kept in the laboratory, estimated that only $10 \%$ of the surviving females incubated a second brood. It was obvious in Nippoleucon hinumensis that all females surviving to April incubated a second brood. These females rapidly disappeared in May, but a small number of ovigerous females were collected in June 1999. This suggests the possibility that long-lived females incubate a third or fourth brood. The 1st instar juveniles, comprising $1 \%$ of the individuals in the summer diapause, had a significantly smaller carapace length than 1st instar juveniles before the diapause. This indicates that the 2 populations differed in origin. Since the 1st manca larvae released from the second brood comprised about 3 to $5 \%$ of the juveniles in May, the small-sized 1 st instar juveniles comprising $1 \%$ of the individuals in diapause can be presumed to derive from the second brood. The duration from emergence to entering the diapause was too short for larvae derived from the second brood to have grown fully and reached the 2nd juvenile instar stage. The small subpopulation of individuals derived from the second brood may not affect the total population of $N$. hinumensis, but there is a possibility (Akiyama \& Yamamoto 2004) that they play a pivotal role in maintaining a subpopulation of individuals without a diapause during their life span (nondiapausing individuals).

There have been few studies on the mating behavior of cumaceans (Duncan 1983), but the death of males soon after mating is a common feature (Duncan 1984). In the case of the highly synchronous postmarsupial development of Nippoleucon hinumensis, most males disappear seasonally. Gamô (1962) reported that all 64 specimens of Leucon varians collected in Tokyo Bay on 29 April 1960 were females: 4 ovigerous specimens and 60 at the preparatory stage. This unusual sample suggests that the life history of $L$. varians is also characterized by synchronous post-marsupial development and abrupt death of the males after mating, as in $N$. hinumensis. Although males became markedly less abundant than females after incubation of the first brood, all females could nevertheless incubate a second brood. The females may retain spermatozoa required for the second brood in their body for the second brood, but another possibility is proposed in Akiyama \& Yamamoto (2004). In the present study, adult individuals, especially preparatory females, showed a patchy distribu- 
tion on the seabed. This suggests a possibility that they use chemical cues for mating.

\section{Fecundity and intramarsupial development}

For the Leuconidae, fecundity has been reported for Leucon nasica (Granger et al. 1979, Corey 1981), L. jonesi (Bishop 1982), L. profundus (Bishop \& Shalla 1994) and Eudorella pusilla (Corey 1981). Fecundity of Nippoleucon hinumensis was characterized by a larger clutch size than the above species, despite its smaller body size. Hashizume \& Omori (1998) reported a large clutch size for an epiplanktonic shrimp of the genus Lucifer living in a bay. The large clutch size of N. hinumensis would also have an ecological role in adaptation to life in a bay or estuary. The marsupium of $N$. hinumensis swells to the limit of its volume at the end of the first brooding, suggesting that marsupium volume determines fecundity for the first brood. Fecundity for the second brood was much smaller than that for the first brood despite the similar body size of the females. The shorter period of the second brood may be related to its shorter vitellogenetic period; the vitellogenetic period was $>1$ mo for the first brood, but only $\sim 20 \mathrm{~d}$ for the second brood.

Previous studies have provided little knowledge about intramarsupial development of the Cumacea; the present temporal data observed in field-collected specimens will be useful as a basis for further studies of cumacean development. The period of the second incubation in early summer was much shorter than that of the first incubation from winter to spring, suggesting that the duration of intramarsupial development is related to metabolic rate, affected by ambient temperature.

Acknowledgements. The authors thank Mr. W. Godo of Ushimado Marine Laboratory for technical assistance. Thanks are also due to Professor Emeritus S. Gamô of Yokohama National University for identification of the specimens. We also thank Dr. I. Gleadall for revision of the English manuscript.

\section{LITERATURE CITED}

Akiyama T, Yamamoto M (2004) Life history of Nippoleucon hinumensis (Crustacea: Cumacea: Leuconidae) in Seto Inland Sea of Japan. II. Non-diapausing subpopulation. Mar Ecol Prog Ser 284:227-235

Alekseev V, Freyer G (eds) (1996) Diapause in Crustacea. Dev Hydrobiol 114:1-241

Bacescu M (1988) Crustaceorum catalogus 7. In: Gruner HE, Holthuis LB (eds) Cumacea I. SPB Academic Publishing, The Hague, p 1-173

Bacescu M (1992) Crustaceorum catalogus 8. In: Gruner HE, Holthuis LB (eds) Cumacea II. SPB Academic Publishing, The Hague, p 175-468
Bishop JDD (1982) The growth, development and reproduction of a deep sea cumacean (Crustacea: Peracarida). Zool J Linn Soc 74:359-380

Bishop JDD, Shalla SH (1994) Discrete seasonal reproduction in an abyssal peracarid crustacean. Deep-Sea Res 41: 1789-1800

Brendonck L, Centeno MD, Persoone G (1996) The influence of processing and temperature conditions on hatching of resting eggs of Streptocephalus proboscideus (Crustacea: Branchiopoda: Anostraca). Dev Hydrobiol 114:99-105

Brendonck L, De Meester L, Hairston N Jr (eds) (1998) Evolutionary and ecological aspects of crustacean diapause. Adv Limnol 52:1-561

Brusca RC, Brusca GJ (2002) Invertebrates, 2nd edn. Sinauer Associates, Sunderland, MA

Cartes JE, Sorbe JC (1996) Temporal population structure in deep-water cumaceans along the western Mediterranean slope (between 400 to $1300 \mathrm{~m}$ ). Deep-Sea Res 43: 1423-1438

Corbera J, San Vicente C, Sorbe JC (2000) Small-scale distribution, life cycle and secondary production of Cumopsis goodsiri in Creixell Beach (western Mediterranean). J Mar Biol Assoc UK 80:271-282

Corey S (1969) The comparative life histories of three Cumacea (Crustacea): Cumopsis goodsiri (Van Benden), Iphinoe trispinosa (Goodsir), and Pseudocuma longicornis (Bate). Can J Zool 47:695-704

Corey S (1976) The life history of Diastylis sculpta Sars, 1871 (Crustacea: Cumacea) in Passamaquoddy Bay, New Brunswick. Can J Zool 54:615-619

Corey S (1981) Comparative fecundity and reproductive strategies in seventeen species of the Cumacea (Crustacea: Peracarida). Mar Biol 62:65-72

Corey S (1983) The life history of Diastylis quadrispinosa (Sars, 1971) (Crustacea: Cumacea) in Passamaquoddy Bay, New Brunswick. Can J Zool 61:108-111

Danilevsky AS (1961) Photoperiodism and seasonal development of insects. Leningrad University Press, Leningrad

DeCaursey PJ (1983) Biological timing. In: Fernberg FJ, Vernberg WB (eds) The biology of Crustacea, Vol 7. Behavior and ecology. Academic Press, New York, p 107-162

Duncan TK (1983) Sexual dimorphism and reproductive behavior in Almyracuma proximoculi (Crustacea: Cumacea): the effect of habitat. Biol Bull (Woods Hole) 165:370-378

Duncan TK (1984) Life history of Almyracuma proximoculi Jones and Burbanck, 1959 (Crustacea: Cumacea) from intertidal fresh-water springs on Cape Cod, Massachusetts. J Crustac Biol 4:356-374

Forsman B (1938) Untersuchungen über die Cumaceen des Skageraks. Zool Bidr Upps 18:1-161

Gage JD, Tyler PA (1991) Deep-sea biology. A natural history of organisms at the deep-sea floor. Cambridge University Press, Cambridge, UK

Gamô S (1962) Two new species of Japanese cumacean Crustacea, Leucon simanensis sp. nov., and L. varians sp. nov. Zool Mag 71:256-261

Gamô S (1967) Studies on the Cumacea (Crustacea, Malacostraca) of Japan. Part I. Publ Seto Mar Biol Lab 15:133-163

Gnewuch WT, Croker RA (1973) Macroinfauna of northern New England marine sand. I. The biology of Mancocuma stellifera Zimmer, 1943 (Crustacea: Cumacea). Can J Zool 51:1011-1020

Granger D, Brunel P, Messier D (1979) Cycle de dévelopment de Leucon nasica (Crustacea, Cumacea) dans la nappe glaciale circalittorale de la baie des Chaleurs, golfe du Saint-Lawrent, en 1968 et 1969. Can J Zool 57:95-106 
Hashizume K, Omori M (1998) Distribution of warm epiplanktonic shrimp of the genus Lucifer (Decapoda; Dendrobranchiata; Sergestinae) in the northwestern Pacific Ocean with special reference to their adaptive features. IOC (Intergov Oceanogr Comm) Workshop Rep 142: $156-162$

Jarre A (1989) Distribution and growth of Diastylis rathkei (Crustacea, Cumacea) in Kiel Bay, Western Baltic. Meeresforsch 32:204-217

Jones NS (1969) The systematics and distribution of Cumacea from depth exceeding 200 meters. Galathea Rep 10:99-180

Klapow LA (1972) Fortnightly molting and reproductive cycles in the sand-beach isopod, Excirolana chiltoni. Biol Bull (Woods Hole) 143:568-591

Krüger K (1940) Zur Lebensgeschichte der Cumacee Diastylis rathkei (Kröyer) in der westlichen Ostsee. Kiel Meeresforsch 3:374-402

Masaki S (1983) Summer diapause. Annu Rev Entomol 25: $1-25$

Neumann D (1981) Tidal and lunar rhythms. In: Aschoff J (ed) Biological rhythms. Handbook of behavioral neurobiology, Vol 4. Plenum Press, London, p 351-380

Editorial responsibility: Otto Kinne (Editor), Oldendorf/Luhe, Germany
Palmer JD (1995) The biological rhythms and clocks of intertidal animals. Oxford University Press, Oxford

Porter KR, Bonneville MA (1973) Fine structure of cells and tissues. Lea \& Febiger, Philadelphia

Roccatagliata D (1991) Claudicuma platense Roccatagliata, 1981 (Cumacea): a new reproductive pattern. J Crustac Biol 11:113-122

Sastry AN (1983) Ecological aspects of reproduction. In: Fernberg FJ, Vernberg WB (eds) The biology of Crustacea. Vol 8. Environmental adaptations. Academic Press, New York, p 179-270

Saunders DS (1982) Insect clocks, 2nd edn. Pergamon Press, Oxford

Stross RG (1996) Significance of photoperiodism and diapause control in the multicycle Crustacean Daphnia pulex Leydig. Dev Hydrobiol 114:107-117

Valentin C, Anger K (1977) In situ studies on the life cycle of Diastylis rathkey (Cumacea: Crustacea). Mar Biol 39: 71-76

Yoda M, Aoki M (2002) Comparative study of benthic and pelagic populations of Bodotria similis (Cumacea) from Izu peninsula, southern Japan. J Crustac Biol 22:543-552

Submitted: January 9, 2004; Accepted: July 15, 2004 Proofs received from author(s): December 1, 2004 